\title{
Priorities in HIV/AIDS Research in Nigeria
}

\section{J.I. Brian-D Adinma and Echendu Adinma ${ }^{2}$}

Departments of 'Obstetrics \& Gynaecology and ${ }^{2}$ Community Medicine, Nnamdi Azikiwe University Teaching Hospital, Nnewi, Nigeria.

"AIDS combat requires aid: Research is the hottest bullet to AIDS destruction" J.I.B

Key Words: HIV, AIDS, Research, Nigeria [Trop J Obstet Gynaecol, 2005, 22: 60-64]

\section{Introduction}

Research remains perhaps the foremost tool in the armamentarium towards the combat of HIV/AIDS, currently the highest ranked amongst contemporary public health problems, the world over. The first report on HIV/AIDS was on $5^{\text {th }}$ June 1981 , by two physicians, one from Los Angeles, California and the other from CDC, Atlanta, Georgia. This was published as a oneparagraph article in the CDC Morbidity and Mortality Weekly Report, of five young male active homosexuals from Los Angeles and New York with Pneumocystis carinii pneumonia. The report in March 1983, of the isolation of a retrovirus (HIV) from the lymph nodes of AIDS patient by Professor Luc Montagnier and his coworkers at the Institute Pasteur, Paris; and the report in May 1984 of the discovery and development of reliable blood tests for the presence of HIV antibody by Dr. Robert Gallo and his colleagues of the National Cancer Institute, USA; are perhaps historical hints that unequivocally highlight the place of research in the management and control of HIV/AIDS.

In Nigeria, for more than fifteen years, following the report of the presence of HIV/AIDS in the country, little or no interest was shown concerning the problem by both the Government and the people alike largely on account of the absence of a scientific data-based information on the magnitude of the problem. The national sero-prevalence Sentinel surveys of 1991, 1993, 1996, 1999, and 2001, no doubt provided the basic information that informed a greater appreciation of the problem at hand, thereby catalyzing Government's interest, with both moral and financial commitment to the combat of HIV/AIDS. The framework for the formation of the National Action Committee on AIDS (NACA) and by extension States and Local Government action committees was set, followed by the development of the HIV/AIDS National Emergency Action Plan (HEAP).

The present political will of government towards aligning to the global fight against HIV/AIDS is indeed a commendable development and the program of action must of necessity be complemented with full blown multi-disciplinary and trans-national research, on a continuing basis for a greater and sustained yield that would justify the human and material premium attached to the fight against HIV/AIDS. To this end it is recommended, that each State or Local Government, or even community action committee on AIDS should be ceded to a genuine research group that would be expected to conduct qualitative research on HIV/AIDS in its area, aimed at giving authentic information on the subject at all times, including monitoring and evaluation of interventional studies on the subject, and helping in no small measure towards charting the correct course towards a successful combat of HIV/AIDS.

It is unthinkable to attempt to exhaust the vast areas of research needs related to HIV/AIDS. This paper will identify research priorities on HIV/AIDS and highlight the most relevant within the context of HIV/AIDS in our environment.

\section{Studies on the HIV/AIDS Virus:}

Following the isolation of the virus, it was called lympho-adenopathy associated virus (LAV) by the French scientists while the American researchers called it Human T-cell Lymphotropic Virus III (HTLV III). The taxonomic imbroglio was ultimately resolved by the International Committee on Taxonomy which called it Human Immuno-deficiency Virus (HIV) '. The virus belongs to the family retroviridae, and sub-family lentivirinae. Before the discovery of AIDS, retroviridae had been known to only infect animals such as:

Horses - Equine Immunodeficiency Virus - worldwide; Monkeys - Simian Immuno deficiency virus - In Africa; Sheep - Feline immunodeficiency virus - In the Middle East.

The current belief is that HIV interacts with the immune system in an incredibly dynamic fashion. The virus is a highly fastidious pathogen capable of replicating very rapidly and mutating strains, especially to anti-retroviral therapy. ${ }^{2}$ Research related to this HIV/Immune System dynamic interaction undoubtedly holds the key towards the development of the HIV/AIDS vaccine, and the development of drugs tailored towards the arrest of the mutagenic capabilities of the virus thereby providing definitive cure of the disease.

Correspondence: Professor J.I.B. Adinma, Department of Obstetrics \& Gynaecology, College of Health Sciences, Nnamdi Azikwe University, P.M.B. 5001, P.M.B. 5001, NNEWI, NIGERIA. 


\section{Epidemiological Studies}

Epidemiological research constitutes the major research pattern for HIV/AIDS in Africa. The time-tested triangle of epidemiologic research consisting of investigations on the host, the agent, and the environment apply no less to HIV/AIDS research. ${ }^{4}$ Epidemiological research on HIV/AIDS must answer questions on what, why, when, how, where and who related to HIV/AIDS so as to provide the necessary information on:

The Frequency,

The Distribution,

The Determinants,

The Deterrents, and

The Control of HIV/AIDS in our environment.

The National Sero-prevalence Sentinel Survey on HIV/AIDS of 1991, 1993, 1996, 1999, 2001 and 2003 and the current estimates of the Nigerian population from the National Population Commission constitute the current authentic national data on HIV/AIDS, and the framework upon which the HIV/AIDS emergency action plan, and projections on HIV/AIDS, for the future, hinge.

\section{Research on Knowledge, Perceptions, Attitude and Behaviour in Respect of HIV/AIDS.}

Research into the distribution and determinants of HIV/AIDS identify amongst other things, cluster areas of high HIV/AIDS epidemics; the vulnerability of youths and women; the very high susceptibility of commercial sex workers, long distance drivers and drug addicts $^{2.35 .6 .7}$. Research focusing on the sexual behaviour of these vulnerable groups, and in particular, condom use and the relationship with their perceptions on HIV/AIDS will give veritable information that will unequivocally aid any action plan on HIV/AIDS combat ${ }^{8,4}$.

\section{Research on Control of HIV/AIDS:}

The control of HIV/AIDS constitutes the most important component of the epidemiological research on HIV/AIDS. Research on control of HIV/AIDS should focus on its four basic approaches:
a. Prevention
b. Anti-retroviral therapy
c. Specific prophylaxis
d. Primary Health Care.

\section{Prevention:}

HIV/AIDS prevention hinges on two major issues

i) Health education of the populace by which adequate information on the epidemiological characteristics of HIV/AIDS, and the devastating consequences of the disease are made available to the populace. Several studies conducted in Nigeria have revealed the poor knowledge, attitude and indeed compliance to universal precautions against HIV/AIDS among hospital workers ${ }^{12,13,14,15,16}$. It is further estimated that $3.9 \%$ to $7.0 \%$ of new HIV/AIDS infections occur globally due to unsafe injection practices ${ }^{17}$. Recent studies have in addition incriminated unsanitary healthcare procedures such as use, and poor disposal, of contaminated needles, syringes and body fluids, as major causes of HIV/AIDS in Africa ${ }^{17}$. Research into identified factors influencing the observance of universal precautions such as ignorance, lack of protective equipments, and infact the unavailability of appropriate work place policy on HIV/AIDS is considered a major priority area of research. Health education related research that creates communication models that facilitate effective counseling and removal of stigmatization in relation to HIV/AIDS is highly desirable.

ii) Prevention of blood-borne HIV transmission. Research on this investigates blood donation screening services; sterilizations of surgical and clinical instruments; evaluating the needle-using practice among quacks and drug addicts ${ }^{10,11}$, and investigating screening for tissue donations such as organ transplantations and therapeutic donors inseminations. A research that investigates the present habits of health workers during routine work may reveal the extent to which these workers appreciate the risk of HIV infection affection affecting them.

\section{Anit-retroviral therapy and HIV/AIDS vaccine:}

The key constraints to the development of drugs that cure AIDS and HIV/AIDS vaccine are related to HIV's rapid replicating capabilities and the development of mutating strains ${ }^{2}$. The discovery of drugs for cure holds the major key to the ultimate control of HIV/AIDS. Local herbs have been observed to cause clinical improvement of patients with full-blown AIDS, and such herbs should be investigated further by researchers.

Immunologist and Pharmacologist researchers have an important role to play towards the harnessing of available herbs to seek the solution to the cure of AIDS in Africa; and the development of vaccines.

Available drugs on HIV/AIDS are very expensive, often toxic and merely improve the well being of the AIDS patient while prolonging life. Drugs that fall within the purchasing power of the common man will undoubtedly have a salutary effect towards the reduction of the devastation to the economy and psychological well being of the AIDS infected and affected persons in developing countries. 
Specific Prophylaxis against HIV/AIDS opportunistic infections:

Apart from the general available prophylactic measures against HIV/AIDS such as sexual abstinence, or sexual discipline; the use of condoms, the avoidance of syringe and needle-sharing; the proper sterilization of hospital instruments after use, precautionary measures with adequate screening before blood transfusion or therapeutic inseminations, and the use of appropriate drugs following risky procedures on HIV/AIDs patients, specific prophylaxis directed at opportunistic infections such as Pneumocystis carinii pneumonia, candidiasis, tuberculosis, etc., must be employed to improve the well-being of HIV/AIDS patients by preventing the occurrence, or reducing the effect, of such infections should they occur. Research that identifies trends in, and new varieties of, opportunistic infections, is considered important in the light of the devastating effects opportunistic infections can impose to the well-being of HIV/AIDS patients. In addition, further research on new and more potent drugs against opportunistic infections, will be most desirable.

\section{Primary Health Care:}

Primary Health care offers grass-root health service to the community. HIV/AIDS impinges on various aspects of Primary Health Care such as maternal and child health; family planning and education. Opportunities abound for grass-root HIV/AIDS research at Primary Healthcare level, and this should be integrated into a base (community) multi-sectoral action committee, in line with the existing structure at national, state and local government levels. Community-based research on HIV/AIDS promises to have far-reaching effect on the national, and indeed global control of HIV/AIDS.

\section{Research related to Monitoring and Evaluation:}

AIDS control surveillance, reporting and record keeping are essential towards HIV/AIDS control. Research that develops an effective surveillance protocol and structured record keeping will undoubtedly facilitate speedier control of HIV/AIDS. A very important, and priority epidemiological research is that on intervention and their impact evaluation. ${ }^{3}$ Monitoring the impact of AIDS/HIV control programs on the community will provide the basis for review of such program on a regular basis, expected to yield better results.

\section{Clinical/Laboratory Studies:}

There are three possible consequences of HIV infection on $\mathrm{CD}_{4}$ cells:-

1. Cell destruction by which inoculation with HIV causes lymph node enlargement with depletion of $\mathrm{T}_{4}$ helper/inducer lymphocytes and ultimate distuption of the normal immune response of the body leading to the development of AIDS related complex (ARC), and ultimate total breakdown of the body's immune system causing clinical AIDS.

2. State of quiescence or latency on the lymphocytes or macrophages without causing clinical disease.

3. Replication in the cells without causing clinical disease. The usual identified course of HIV infection include -

- Inoculation of the Virus

- A window period of 6 to 24 weeks during which sero-conversion occurs

- An incubation period of 3 to 10 years between initial inoculation and the development of full blown AIDS. All these stages in the clinical course of HIV/AIDS offer research potentials on interventions precautionary, therapeutic, etc.

Clinical manifestations of AIDS are the necessary tools towards the clinical diagnosis of AIDS, AIDS related complexes, and AIDS related Diseases. Protean manifestations can occur, affecting virtually all the systems of the body, and therefore cuts across all the medical and related specialties and the guarding researcher must at all times look out for the vast research potentials possible from this. Clinical entities and manifestations hitherto unknown may become exposed through the suspicion and anticipation of the guarding researcher.

Laboratory investigations of various forms and specificity have been developed in the course of the fight against HIV/AIDS. Laboratory testing alone, it is worthy to note, cannot be used to diagnose AIDS even if the recommended investigation of reactive specimens suggest a high probability that the antibody to HIV is present. A negative test result at any point in the investigation therefore does not preclude the possibility of exposure to, or infection with HIV ${ }^{17}$.

There are identified reasons for HIV testing and these include

- Screening of donated blood

- Routine HIV testing before marriage, employment or taking an insurance policy.

- HIV testing for individuals at risk such as recipients of contaminated blood; sexual contacts of infected persons, and persons with needle-pricks etc.

- Confirmation of clinical diagnosis of AIDS

- HIV/AIDS active surveillance.

Research into the attitudes of people to HIV testing, and those that will highlight the voluntary and confidential nature of HIV testing hold promise as a major instrument for HIV/AIDS prevention and control.

Tests have been developed for blood, and saliva and these include:

- Enzyme-linked immuno-absorbent assay (ELISA);

- Indirect fluorescin Assay; (IFA) 
- Radio-immuno precipitation Assay (RIPA)

- Western Blot(WB)

- Electron microscopy (EM)

- Polymerase chain reaction (PCR).

A major hindrance to the conduct of these tests, however, is cost consideration.

Research into simpler, cheaper, available and affordable and yet sensitive test kits is, therefore, highly desirable.

\section{Studies on HIV/AIDS Management:}

To date there is no definitive cure for HIV/AIDS. Available drugs merely improve the well being of the AIDS patient and prolong life. Available drugs are often expensive and are out-of-reach of the average AIDS patient in the developing country where presently up to $90 \%$ of new infections are occurring.

\section{Research Related to Care and Support of People} Living with HIV/AIDS:

Apart from the desirability to develop effective drugs and vaccines against HIV/AIDS, it is important to focus, in addition on research related to other aspects of care and support of HIV/AIDS patients. These include research related to:
\& Nutrition
$\infty$ Exercise
$\curvearrowright$ Immune boosters
$\infty$ Spiritual support

Furthermore, a research that examines the feelings, concerns and needs of HIV infected and affected persons, need for a HIV-cure center; assess the psychological impact of people living with HIV are desirable to provide guided support and counseling in HIV/AIDS management. A research that will examine the attitude of the society to the HIV-infected patient, and the role of education towards these attitudes, is also desirable.

Research into the role of faith-based care in the management of HIV/AIDS patient is a high premium

\section{References}

1. Park K. Epidemiology of communicable diseases. Surface Infections: AIDS.

In: Park's textbook of Preventive and social Medicine, 15th edition, $1997 ; 258$.

2. Henry $\mathrm{K}$, Melroe $\mathrm{H}$, Nelson R. Directions in HIV/AIDS research: A Minnesota Perspective. Minn Med, 1995; 78(11): 26-34.

3. De-Cock KM, Ekpini E, Gnaore E, Kadio A, Gayle HD. The Public health implications of AIDS research in Africa. $J A M A$, 1994;272(6): 481-486.

4. Sharar RG. General Principles of epidemiology. In: Cassens BJ (ed), Preventive Medicine and Public Health (NMS), $2^{\text {nd }}$ edition. Hongkong, London, Baltimore: Williams and Wilkins, 1992; 129. research, since religious-spiritual support at home, hospital or community has been observed to offer strength and comfort albeit psychologically to such patients.

Research into the role of stress-reduction in the management of the HIV/AIDS patient also carries promise.

Studies on the Economic and Social Impact of HIV/AIDS on the Nation

HIV/AIDS infection causes a progressive decline in productivity of the workforce especially in countries where the prevalence rate is high. Research that evaluates the economic loss to the country through declining productivity is desirable.

The family perhaps remains the worst hit and the psychosocial impact of HIV/AIDS related deaths on the immediate, and extended family of the victim is a green area for study. The plight of the orphans from AIDS deaths can be investigated on short-term basis and short and long-term needs, and projections towards their management proffered.

There is also need to investigate unexplained deaths in the community, and indirect deductions on the basis of symptomatology, as to the extent of AIDS mortality made.

In conclusion, HIV/AIDS research as covered in this article is not exhaustive, but none-the-less highlights green and priority areas expected to guide researchers. Research is demanding, and resource constraints money, staff and time often militate against the achievement of quality research ${ }^{18}$. Eastaugh ${ }^{19}$ had observed that funding agencies on HIV/AIDS research often face cost-identification problems and had suggested the desirability of a stable, fair, funding mechanism that would aid these funding agencies. Research is dynamic and information from good research invariably breeds further research until the desired goal of the researcher, the funder and the society at large is achieved.

5. Orubuloye IO, Caldwell J, Caldwell P. The role of high risk occupation in the spread of AIDS: Truck Drivers and itinerant market women in Nigeria. Int Fam Plan Perspect, 1993; 19(20): 43-48.

6. Orubuloye IO, Caldwell P, Caldwell J. Commercial sex workers in Nigeria in the Shadow of AIDS. In: Orubuloye IO et al (eds). Sexual networking and AIDS in Sub-Saharan Africa, Behavioural research and the social context, Health transition series, No.4. Canberra: The Australian National University, $1994 ; 101-116$.

7. Orubuloye IO. Research needs relating to the behavioural aspects of STD/AIDS in Nigeria. Paper Presented at The Seminar on Research Priorities in Reproductive Health in Nigeria held at Obafemi Awolowo University, Ile-Ife, 3-5 5 " June, 1996. 
8. Adinma JIB, Agbai AO, Okeke AO. Sexual behaviour and pregnancy among Nigerian students. Adv Contracept, 1994; $10: 265-279$.

9. Adinma JIB. Sexuality in Nigeria pregnant women: Perceptions and proctae. Aust NZ J Obstet Gynaecol, 1995; 29(1);30-34.

10. Friedman SR, Jose B, Deren S, Des-Jarlais DC, Neaigus A. Risk factors for Human Immunodeficiency Virus. $A m J$ Epidemiol, 1995; 142(8): 864-874.

11. Kail BL, Watson DD, Ray S. Needle-using practices within the sex industry. National AIDS research consortum. Am J Drug Alcohol Abuse, 1995; 21(2): 241-255.

12 Ofili AN, Asuzu MC, Okojie OH. Knowledge and practice of universal precautions among nurses in Central Hospital, BeninCity, Edo State, Nigeria. Niger Postgrad Med J, 2003; 1:26 31.

13 Adebamowo CA, Ezeome ER, Ajuwon JA, Ogundiran TO. Survey of the knowledge, attitude and practice of Nigerian surgery trainees to HIV-infected persons and AIDS patients. BMC Surg, 2002;2(1): 7.
14 Atulomah NO, Oladepo O. Knowledge, perception and practice with regards to occupational risks of HIV/AIDS among nursing and midwifery students in Ibadan, Nigeria. Afri J Med Med Sci, 2002; 3:223 227.

15 Owotade FJ, Ogunbodede EO, Sowande OA. HIV/AIDS pandemic and surgical practice in a Nigerian teaching hospital. Tropical Doctor, 2003; 33(4): 228231.

16 Odunjirin OM, Adegoke OA. AIDS: awareness and blood handling practices of health care workers in Lagos, Nigeria. Eur JEpidemiol, 1995; 11(4):425 430.

17 Ijezie JN. AIDS and the Medical Practitioner. Guest lecture delivered at the Clinical Update Meeting of the Nigeria Medical Association, Onitsha zone, Onitsha Nigeria 12 May, 1996.

18 Difranceisco W, Kelly JA, Otto-Salaj L, McAuliffe TL, Somlai AM, Hack LK, et al. Factors influencing attitudes within AIDS service organizations towards the use of research-based HIV prevention interventions. AIDS Educ Prev, 1999; 11(1): 72-86.

19. Eastaugh SR. Financial Issues in Defining Levels for HIV/AIDS Research. JHealth Care Finance, 1995;25(1): 19. 